\title{
GOOD PRACTICES FOR SUSTAINABILITY OF RURAL AREAS IN BULGARIA
}

\author{
Hristina Harizanova \\ University of National and World Economy, Department Natural Resources Sofia, Bulgaria \\ hharizanova@unwe.acad.bg
}

\begin{abstract}
Changes in agricultural sector policies are crucial to reach successful rural development in Bulgaria. Scientific and practical interests are the main factors which lead to changes in the sector by using best practices in the regions. The main aim of the paper is to evaluate the best practices and lessons for reaching sustainability in the rural areas in Bulgaria. Rural development and funds should comply with appropriate best practices for sustainability. In the first part of the paper are analyzed theories about sustainability in rural areas, connected with best practices. The paper also includes evaluation of main factors which affect rural development in Bulgaria. Assessment of factors influencing rural development is very important to target resources to overcome the negative impacts and enhance positive effects of some of the factors for sustainable development. On this base general conclusions are proposed for using best practices for sustainability. The paper is based on results from research conducted by experts in the field of agricultural policy.
\end{abstract}

Key words: agricultural sector; best practices; sustainability

\section{ДОБРИ ПРАКТИКИ ЗА ОДРЖЛИВОСТ НА РУРАЛНИТЕ ОБЛАСТИ ВО БУГАРИЈА}

Промените на политиките во земјоделскиот сектор се клучни за постигнување успешен рурален развој во Бугарија. Научните и практичните интереси се главни фактори кои доведуваат до промени со користење на најдобрите практики во регионите. Главна цел на овој труд е да се оценат најдобрите практики и лекции за постигнување на одржливост во руралните средини во Бугарија. Руралниот развој и фондовите треба да се усогласат со соодветните најдобри практики за одржливост. Во првиот дел од трудот се анализираат теории за одржливоста во руралните области, поврзани со најдобрите практики. Трудот вклучува и оценка на главните фактори кои влијаат врз руралниот развој во Бугарија. Проценката на факторите кои влијаат врз руралниот развој е многу важна за да се наведат ресурсите за надминување на негативните влијанија и подобрување на позитивните ефекти на некои од факторите за одржлив развој. Врз оваа основа се предложените генерални заклучоци за користење на најдобрите практики за одржливост. Трудот е врз основа на резултатите од истражувањето спроведен од страна на експерти во областа на земјоделската политика.

Клучни зборови: земјоделски сектор; најдобри практики; одржливост

\section{INTRODUCTION}

The sustainable development is a state of art conception especially when we talk about Regional sustainability. To achieve sustainability on regional level sustainability in the whole country has to be reached. According to this statement each single municipality has to propose the combination of current measures as most appropriate for sustainability. Furthermore the sustainability is connected with the theory of economic growth and GDP. (Monasterolo 2010). Some authors find the connections between increasing GDP per capita, better lifestyle and better perspective for measures about environment on local level. Gocht \& Norbert (2010) have the same opinion which explains that the politics has to develop exact area. Sustainability is shown as a way to getds all kind of activities which will make better opportunities for business units and environment. Sustainability on the municipality level can be reached as a highlight of social, ecological, structural, and economic sustainability on the local level (Harizanova, Stoyanova, Sterev 2011). For this purpose first we have to try to find some definitions about the rural region, and on this base to propose best practices for 
achieving sustainability in it. In European legislation and practice there is still no single definition of rural area. The main reasons are indicated $(\mathrm{Ec}$, 2006) as follows:

- Different views on which elements in most rural areas are characterized (natural resources, economic environment, cultural heritage);

- Practice to formulate different definitions, depending on the purpose and nature of the research (geographical, economic, agricultural) and construction of the development policies;

- Inadequate access to statistical information at smaller administrative units.One of the objectives of the Common Agricultural Policy is ensuring a reasonable living standard of farmers and other supply consumers with quality food at reasonable prices for them. In recent years, these goals have undergone many changes. Recently, increasing attention is paid to food safety, preservation of environment and relationship between quality and price.

Many authors (Mishev 2008, Salasan 2009) have bean working to evaluate the current measures and the effect on the agricultural sector as well as they are searching for ways to prevent poverty in rural regions in the countries. The main objectives in every country in the agricultural sector are:

- Agricultural production to become modern and competitive, to provide employment in the agricultural sector and good income, which can ensure them better living standards.

- Agricultural sector to be sustainable, taking into accounts the hygiene requirements for safety and quality of production in harmony with the environment and to follow good agricultural practices.

- To simplify procedures and access to information on agricultural policy applied. In addition it is important that each side knows clearly what is required of it and how to change agriculture to enable a greater extent to meet the above objectives.

The European model of agriculture enables each Member State alone to determine the boundaries between efficient farming and sufficiently profitable for different production structures.

As a weakness of the European model of agriculture, it may be noted that the way you need to achieve the objectives is not mapped. For a structure as a semi-market economy it should be made of concrete measures by which it can be supported.

\section{MATERIAL AND METHODS}

The main aim in this paper is to evaluate some of the best practices which may lead the sustainability in the area. A large number of qualitative and quantitative methods may be used in order to make extensive research on good practices of rural Bulgaria. The main objective of the analysis is to reveal the essential good practices in rural regions in Bulgaria which could bring better development in the regions. The questionnaire was developed under the project SCARLED. Bulgarian part included 10 experts operating in the agricultural area. In addition the database was increased by collecting opinions from other 40 persons who work in agricultural services. Based on the developed strategies for sustainable development of each area the most common priorities have been taken. The priorities were suggested by experts as the best possible practices. Their role was to give their opinion and to assess whether the proposed practices really contributed to achieve the objectives of the strategies.

The main purpose of this paper is to evaluate the best practices in rural areas. In policies the aim is rural development and evaluation of best practices and on this basis to make generalized conclusions for future development of these regions. The report is based on data which is a part of the research project SCARLED. Respondents are experts in the field of agriculture. The study was conducted in 2010 and developed more into 2011. The questions proposed to the experts in Bulgaria were to evaluate best agricultural practices in order to reach sustainability in rural regions. The scores given by them are from 1 to 5 . On the basis of average assessment a conclusion of the proposed lessons of the best practices for implementing rural development, was drawn, where 1 is strongly disagree and 5 strongly agree.

\section{RESULTS AND DISCUSSIONS}

Best practices in rural regions are show possibilities for faster transformation to sustainability in the researched area. For this purpose several questions were performed about good practices which may lead sustainability. Questions were based on regional strategies. For this reason, many experts are part of the regional offices of the studied areas. Another part of the respondents are individuals, experts working in agriculture in practice science and theory. After collecting opinions they 
are measured by a scale from 1 to 5 shown on the table below (Table 1). All experts evaluated best practices in their region. The idea is to show practices which are capable to reach sustainability.

\section{Table 1}

\section{Best practices for implementing rural sustainability - high scored}

Participation of local entrepreneurs in the rural

development process should be encouraged

Rural development policy should ensure a more balanced distribution of funds between agricultural and non-agricultural measures

New regional structures and institutions capable of attracting and administering and monitoring EU funds should be created

Responsibilities for planning and implementation of rural policy should be decentralised on the regional level

Design and implementation of rural policy should be based on a territorial approach

Rural development policy should be embedded within a clear regional strategy

Source: Scarled database, Delphi survey, 2010,2011

The most important best lesson for reaching sustainability in rural areas is "participation of local entrepreneurs in the rural development process should be encouraged". All experts in this survey evaluated this best practice with the highest possible score 5 . This statement has full support because all experts are of the opinion that for reaching sustainability in rural areas the most important there is the local business to have nice conditions for operating there. Some of the experts supported the opinion that developing the infrastructure should be made mostly for creating possibilities for local business to become more successful. On the next place is score 4.7 from 5 where for reaching sustainability in rural areas it is very important funds for agricultural and non agricultural sectors to be balanced. Even many industries are situated with mainly agricultural activities in rural area in Bulgaria. On open talks with interviewed persons this distribution should be directed to food processing industries. This will give possibilities for horizontal and vertical integration of business operated in the area of agricultural and non agricultural spherees. The combination of food processing industry and raw materials is a agreat possibility for decre- asing expenditures of both sides. An other high evaluated practice is "New regional structures and institutions capable of attracting and administering and monitoring EU funds should be created". The given score is 4.2. This shows that in this stage Bulgaria is not fully capable structures to achieve sustainability with the existing. Experts point that it is very important for better results and development of the region the implementation of local policy to be made on the territorial approach. In addition to this statement the responsibilities of implementing these policies should be overtaken by local services, who will monitor and control the processes on the territory. These proposals are made because of the differentiation of the regions in Bulgaria and if one approach could lead sustainability in one region, it doesn't mean it will lead sustainability in the other region in Bulgaria. All politics and lessons should be conducted by local services who will know best the current conditions in the regions where they operate. In regional strategies when they are developed, should be taken under attention exactly the difference of the region and to be proposed plans for development to each municipality. These words are supported by score of 4.1 of the experts opinion.

Table 2 shows the rest best practices which may lead to sustainability. All of them are evaluated with lower scores than those in Table one. The highest score among these lessons is "New national structures and institutions capable of attracting and administering and monitoring EU funds should be created". This can be explained with the best lesson in Table one, where it is pointed that it is more important these institutions to be on the local level, not on the national one. The total score which this lesson reached is 3.4 , which is close to the neutral practice in rural regions in Bulgaria for archiving sustainability. The experts do not agree a lot with the opinion "Capacity building is weak in my region and should be enhanced at all levels", because they do believe that each region like independent one can reach sustainability if it receives power to manage the funds from EU. The experts as well do not think in the regions there is a lack of social interaction/networking which constrains rural development. This practice is very low evaluated, and has only 3.3 scores which made it neutral for reaching good development in the regions. The program LEADER is also on one of the lowest positions. The main reason is that on this stage, when the survey was conducted this program was almost unknown and only a few projects were launched. "A considerable share of rural funds should be in- 
vested in human capital through education and training in rural areas" is the best practice that has the lowest score of all questions in the survey. The given score by experts is 2.8. The explanation was that in latest years in Bulgaria many universities and colleges were opened in rural regions in Bulgaria. This is the main reason why this lesson does not have such a big inflection for sustainability in rural areas at this moment.

\section{Table 2}

Best practices for implementing rural sustainability-low scored

New national structures and institutions capable of attracting and administering and monitoring EU funds should be created

Capacity building is weak in my region and should be enhanced at all levels

A lack of social interaction/networking constrains rural development in my region; social capital should thus be improved at all levels

Local stakeholders and regional authorities should be involved to develop and implement projects, such as with LEADER

A considerable share of rural funds should be invested in human capital through education and training in rural areas

Source: Scarled database, Delphi survey, 2010, 2011

\section{CONCLUSIONS}

Most of the proposed practices are very important for the sustainable development of the regions, but the most important is the possibility for encouraging the development of local businesses. The new employment in the sector will support the sustainable development of the Region where the firms operate. The development of the infrastructure in rural regions is one of the most important factors for reaching sustainability. Developed infrastructure gives rise to other areas of sustainability. Also, the combination of elements of sustainability and the best practices can improve living conditions. Balanced use of the funds for nonagricultural and agricultural support is also one way of improving the rural areas in Bulgaria. An- other conclusion is that if funds are managed by local bodies, much more successful would be their absorption rate, and the results will be better as well. Among the best practices there are some, which according to the opinions of the experts at this stage are not so important. The most unimportant best lesson is investment in human capital through education and training in rural areas and program LEADER. Probably in the next period the ranking will be changed, but at this stage, for developing the regions the government needs to pay a lot of attention to reach sustainability by supporting local busineses.

Acknowledgements. The paper is based on data by Project CN-44201 SCARLED. The included questions are updated 2011, by taking additional experts involved in the survey.

\section{REFERENCES}

[1] Mishev P. (2008): Trends in agriculture in the world and changes in the CAP Scientific-practical conference "Changes in the Common Agricultural Policy and Bulgaria's position", University press „Stopanstvo”

[2] Project CN-44201 SCARLED "Structural Change in Agricultural and Rural Livelihoods", partner for Bulgaria prof. Plamen Mishev, database Delphi-2010.

[3] Salasan, C., Fritzsch, J. (2009): The role of agriculture for overcoming rural poverty in Romania, Discussion Paper No. 121, Leibniz Institute of Agricultural Development in Central and Eastern Europe (IAMO), Halle (Saale), Germany.

[4] Heijman Win, Milic, Branislav B., Bogdanov, Natalija (2011): The "Rural-Sensitive Evaluation Model" for evaluation of local governments' sensitivity to rural issues in Serbia, $122^{\text {nd }}$ Seminar, February 17-18, 2011, Ancona, Italy, No 99417.

[5] Gocht A., Roeder N. (2010): Recovering localized information on agricultural structure underlying data confidentiality regulations - potentials of different data aggregation and segregation techniques - 9 German association of agricultural economists (gewisola), 50th Annual conference, Braunschweig, Germany, September 29 - October 1, 2010.

[6] Monasterolo I., Coppola N. (2010): Slovenia Mapping Serbia: more targeted rural areas for better policies 118th seminar, August 25-27, 2010, Ljubljana.

[7] Harizanova, Hristina, Stoyanova, Zornica, Nikolay Sterev (2011): Development of Food and beverage sector to achieve sustainability in North Central Region of Bulgaria, Poster Session Paper prepared for presentation at the 2011 EAAE PhD Workshop, Nitra, Slovak Republic, April 27-29, 2011. 